\title{
'N SOSIOLOGIESE VERKENNING VAN ONS JEUGPROBLEMATIEK
}

DR. A. BREEDT

I. INLEIDING.

Wanneer die sosioloog 'n on derwerp soos hierdie moet hanteer, kan hy hom van verskillende benaderingswyses bedien. So, byvoorbeeld, kan hy 'n uitvoerige beskrywing, rubrisering en kwantifisering van die betrokke verskynsel weergee. Dit sal o.a. meebring dat 'n massale meningsopname met die daaropvolgende dokumentasie van gegewens, karakterisering van proefpersone, statistiese verwerking en dergelike meer, onderneem moet word. In sodanige ondersoeke ontbeer die navorser gewoonlik kostelike kennis, soos bv., die belewing van groepsgebeure, die wyse waarop groepe funksioneer, wisselende strukture daarvan en die onderlinge samehang en interafhanklikheid tussen groepe.

'n Ander weg wat ingeslaan kan word, is om die jeug, as sosiale kategorie en as sosiale struktuur, te betrag binne die raamwerk van die samelewingstruktuur waarvan hulle lede is. Hierdie benadering impliseer egter dat van etlike veronderstellings uitgegaan word, waaronder dat die jeug as 'n onderskeidende kategorie in die sosiale struktuur voorkom, dat daar 'n hoë mate van onderlinge interaksie tussen jeugdiges bestaan en dat jeugdiges op ' $n$ besondere wyse gestalte gee aan die gemeenskaplikheid van hulle samesyn. Dit hou ook in dat die struktuur-geheel van die jongmens aan allerlei ontwikkelinge onderhewig is. Van Hessen som die situasie raak op wanneer hy soos volg skryf: ,In strikte zin spreken wij dan ook van jeugd als van een gestructureerd samen jong zijn dat moet worden gezien in het verband en verloop van een bepaalde samenlevingseenheid"' (sy kursivering). ${ }^{1}$ )

Vir die doeleindes van die hieropvolgende bespreking word die aksent op laasgemelde benadering geplaas. Daar sal derhalwe getrag word om 'n oorsigtelike beeld te gee van die samelewingstruktuur waarin die jeugverskynsels en -vraagstukke voorkom. By al die voordele verbonde aan die gebruikmaking van hierdie benaderingswyse, hou dit ook die groot nadeel in dat 'n mens uiteraard nie 'n volledige en deeglike analise van die huidige situasie kan maak nie, gevolglik word slegs in breë trekke op sekere fasette gedui, bewus daarvan dat sodanige fasette nie noodwendig die belangrikste elemente van die huidige samelewingstruktuur verteenwoordig nie.

Dit word allerweë erken dat ons vandag in 'n tydperk leef wat een van die belangrikste periodes van transformasie in die menslike geskiedenis vorm. Diegene wat hulle verknies oor die feit dat hulle nie geleef het in die tyd van 'n Caesar of ' $n$ Napoleon toe geweldige veranderinge die wêreld getref het nie, hoef nie vandag teleurgesteld 
te wees nie. Ons leef in 'n era waarin omwentelinge vinniger, aangrypender en skouspelagtiger as ooit vantevore op mekaar volg. Dit is verder ook duidelik dat die veranderinge wat voorlê, teen 'n nog sneller tempo sal volg. Dit plaas geweldige stremminge en spanning op die houdbaarheid van ons maatskaplike struktuur en verg voortdurende herevaluasie en aanpassing ten einde krisistoestande en ineenstorting die hoof te bied.

Die kompleksiteit van die twintigste eeuse samelewing blyk duidelik wanneer 'n voëlvlug oor die voorafgaande eeue onderneem word. ${ }^{2}$ )

Die middeleeuse samelewing was in sy samestelling sterk op die patriargale familieverhouding gevestig. Die mens het in 'n klein, geslote gemeenskap gelewe waarin die familieverwantskap sy hele lewe beheers en sinvolheid gegee het. Die lewensgenot van hierdie tyd word dan ook gekenmerk deur 'n sterk familiaal georiënteerde gemeenskapsbesef en 'n teosentriese lewenshouding. Die kerk neem in die middeleeue 'n sentrale plek in.

Die Renaissance bring 'n historiese beweging van diepgrypende aard mee. Die mens word nou ontkoppel aan die religieuse en sosiale bindinge van die middeleeue. Die mens ontdek homself as individu. Namate die proses van emansipasie en sekularisasie toeneem, word die mens in 'n groter mate 'n selfstandige persoonlikheid met eie denke en 'n eie wil. Die mens word nou nie meer gesien as 'n skepsel van God en as 'n groepwese nie, maar as 'n individu, 'n selfstandige persoonlikheid wat volgens sy eie beginsels leef en sy omgewing beïnvloed.

Hierna volg die periode van die Franse Rewolusie voorafgegaan deur die Reformasie en kontra Reformasie, waarin die proses van emansipasie en sekularisasie teen versnelde tempo voortstu. Hierdie tydvak word gekenmerk deur 'n onweerlegbare vertroue in die menslike rede en 'n diepe wantroue teenoor enige vorm van tradisie en gesag. Die tradisionalisme moet swig voor die aanvalle van die rasionalisme. Hierbenewens woed, afgesien van die rewolusie op politieke gebied, ook nog die industriële rewolusie op ekonomiese gebied met die daaruit voortvloeiende kapitalisme.

Die proses van emansipasie en sekularisasie bereik sy hoogtepunt in die negentiende en twintigste eeu en word in die opsig veral deur vier maatskaplike dryfkragte verstewig, $\mathrm{nl}$. die enorme ontwikkeling van die industrialisme; die moderne, volgroeide kapitalisme met sy gees van winsbejag; die grootskaalse proses van verstedeliking en die verhoogde sosiale mobiliteit in sowel die horisontale as vertikale vlak.

Hierby kan sekerlik nog die chaos van twee wêreldoorloë, onder wie se gedruis die proses van emansipasie en sekularisasie voortgesit is, gevoeg word. Gemelde proses beklee hom nou in 'n 
kleed van liberalisme waarin die menslike samelewing gesien word as ' $n$ ongestruktureerde losse samevoeging van outonome individue.

Met die bevryding van die mens uit die organiese bindinge van weleer, beland hy nou in ' $n$ netwerk van organisasies en instellings wat ingerig word ter beveiliging van sy velerlei belange. Dit beteken ' $n$ versaakliking en instrumentalisering van menslike betrekkinge... 'n oorgang in die westerse samelewing van 'n oorwegend ,gemeinschaftliche" na "n oorheersend .gesellschaftliche" georganiseerde maatskaplike struktuur. Kenmerkend van hierdie nuwe maatskaplike struktuur is 'n gees van strenge saaklikheid en nuttigheid waardeur menslike omgang meer en meer onpersoonlik raak. Dit lei daartoe dat die mens dikwels andere slegs sien as ' $n$ middel of werktuig wat hy in die nastrewing van sy eie belange kan benut.

Teen die agtergrond van die bondige uiteensetting hierbo, sal vervolgens gepoog word om op enkele fasette van ons hedendaagse samelewingstruktuur te let. Allereers moet egter beklemtoon word dat hierdie ' $n$ sosiologiese verkenning van die jeugproblematiek is. M.a.w., die veronderstelde benadering is gegrond op ' $n$ bepaalde vakwetenskaplike uitgangspunt en boonop is dit spesifiek 'n verkenning, waarmee geïmpliseer word dat hiermee nog geensins die laaste woord gespreek is nie. Inteendeel, hierdie bespreking moet juis gesien word as 'n poging om verdere navorsing in dié verband te stimuleer. Voorts wil nie ingeval word by die haarklowery oor wat presies met „jeug" bedoel word nie. Genoegsaam om te sê dat wanneer voortaan van ,jeug" gepraat word, daar na ' $n$ bepaalde tydperk in die mens se lewe verwys word. Hoewel geen bepaalde ouderdomsgroepe as maatstaf geneem word nie, het dit tog praktiese waarde om te weet dat sowel die puberteitsjare as die adolessensie hiermee veronderstel word, d.w.s. 'n tydperk wat min of meer vanaf 13 jaar tot ongeveer die vroeë twintigerjare (selfs tot 25 jaar) strek. $\left.{ }^{3}\right)$

Vervolgens word kortliks gelet op enkele fasette van die samelewing waarin die jeug van vandag hulle bevind, waarna 'n poging aangewend sal word om ' $n$ paar riglyne neer te lê waarlangs die huidige jeugproblematiek moontlik die hoof gebied kan word.

\section{DIE WERELD VAN DIE JEUG.}

\section{1. 'n Tegniese wêreld.}

Die wetenskap en tegniek kleur tot op 'n groot hoogte die beeld van die wêreld waarin die jeug vandag leef. Hierdie kennis sal ook in 'n steeds groter mate die toekoms van die mens, sy materiële lewe, sy medemenslikheid en sy persoonlikheid beheers. Van Echelpoel konstateer in die verband die volgende: „Met een steeds kleiner wordende afstand tussen wetenschappelijke ontdekking, laboratoriumproduktie en produktie voor algemene konsumptie 
wordt bij elke wetenschappelijke vooruitgang een mogelijkheid geschapen die op korte of langere termijn een weerslag zal hebben op de menslijke persoon en samenleving. ${ }^{\prime \prime}$ )

Met die toenemende vertegnisering en outomatisering van die samelewing, word feitlik elke afsonderlike politieke, sosiale of ekonomiese probleem vandag noodsaaklikerwys 'n wêreldprobleem. Die kommunikasienetwerk bring vandag die hele wêreld in ons sitkamer. Ons en die Russe is vandag baie nader aan mekaar as 'n Vaalpens en 'n Bolander van 'n halwe eeu gelede. Hierdie tegniese moontlikhede bepaal ook produksie en konsumpsie. Vandaar dat ons vandag met reg kan praat van 'n konsumpsiemaatskappy.

Die aspekte wat voorts beklemtoon gaan word, hou amper deurgaans regstreeks verband met hierdie wetenskaplike en tegniese vooruitgang. So, bv., kan verwys word na die toenemende mate van verstedeliking, die massafikasie van die mens, die verhouding arbeid-vrye tyd, die evolusie van die materialisme ensomeer. Dit is nouliks nodig om te beklemtoon watter invloed die wetenskap en tegniek op die lewenshouding en lewensbeskouing van 'n samelewing kan uitoefen. Die jeug ervaar hierdie tegniese en veranderende wêreld as vanselfsprekend en verstom nie van verbasing soos sommige van die ouer geslag wat nog herinneringe van die ossewa en die trem vertroetel nie.

\section{Verstedeliking.}

Een van die belangrikste sosiale rewolusies van die afgelope eeu was die proses van verstedeliking wat hom regoor die wêreld voorgedoen het. Hierdie proses is o.a. die resultaat van 'n toename in die bevolking, industrialisasie en soms 'n patologiese stadpsigose. die stad sentreer veral om gespesialiseerde sekondêre asook sekere tersiêre funksies. Dit kan verwag word dat die verstedelikingsproses ook sal toeneem namate die wetenskaplike en tegniese evolusie tot nog groter spesialisasie en outomatisasie aanleiding gee. 'n Illustrasie hiervan is, bv., die feit dat in 1800 slegs $1,3 \%$ van die wêreldbevolking in stede van 100000 of meer inwoners woonagtig was, terwyl hierdie syfer in 1930 tot $11 \%$ en in 1964 tot $13 \%$ gestyg het. ${ }^{\overline{5}}$ ) Volgens projeksies wat die Afrikaanse Handelsinstituut nou onlangs vrygestel het, word bereken dat $95,8 \%$ van die Blankes in Suid-Afrika teen die jaar 2000 in stede sal woon.

Verstedeliking het ook heelwat sosiale veranderinge teweeggebring. Een van die opvallendste kenmerke van 'n stedelike lewenspatroon is die diversifikasie van verskillende lewensfunksies, bv. ten opsigte van die arbeid, woontoestande, ontspanning en vryetydsbesteding, die opvoeding ensomeer. Boonop bring verstedeliking ook altyd 'n grootskaalse sosiale mobiliteit en anonimiteit mee. Menslike verhoudinge is louter funksioneel en saaklik van aard. 
Die vriendekring asmede die groepsbindinge, bv. in sport- of verenigsingslewe, word nie noodwendig deur die woonomgewing bepaal nie. Tereg spreek Van Echelpoel kommer uit wanneer hy soos volg opmerk: "Dit veelvoud van relaties en deze grote keuzevrijheid bieden mogelijkheden voor een ruimere menselijke ontplooiing, maar stellen de facto eveneens het probleem van de verecnzaming in de anonieme massa voor al diegenen die om gelijk welke reden er niet in slagen deze vrijheid te doen funktioneren in een bewuste keuze van relaties. ${ }^{\circ}$ )

Die stad word voorts as die tradisionele broeiplek van die sosiaal-patologiese verskynsels beskou. Georganiseerde misdaad, prostitusie, selfmoord, alkoholisme, gesinsdisorganisasie, geestesafwykings en dergelike meer word gewoonlik met die stadslewe geassosieer. In hierdie verband moet nie nagelaat word om te noem watter ontwortelende effek die uitbreiding van die stedelike invloed na die platteland gehad het nie. Die stedelike lewenswyse, ideale, gewoontes en gebruike sypel teen 'n snelle tempo deur na die landelike areas. Die ware karakteristieke eienskappe van die landelike instellings en lewenswyse word slegs nog op werklik geisoleerde dele van ons land aangetref.

Die stedelike lewenspatroon is by uitstek die groeibodem van ' $n$ sterk pluralistiese samelewing en is direk eweredig met die massafikasie van die hedendaagse stadsmens.

\section{Massafikasie.}

Gedurende die afgelope vier tot vyf dekades het sosiaal-kulturele kragte en die ontwikkelinge op wetenskaplike en tegniese gebied omwentelinge ingelui waarvan die konsekwensies nog nie ten volle besef word nie. In hierdie verband kan, bv., net gedink word aan die snelle uitbreiding en werking van die verskillende massakommunikasiemedia (gedrukte woord, radio, rolprent en televisie), waardeur oordraging na so te sê die hele wêreld plaasvind en die inwerking daarvan deur die "massa" ondervind word.

Een van die belangrikste gevolge van die massakommunikasie is dat die sogenaamde massamens na vore tree. "Hoewel die term massamens ' $n$ vae begrip geword het", aldus Cronjé, ,is een van sy kenmerke tog wel opvallend, nl. dat hy een van die massa (menigte) word en soos die massa (die oorgrote meerderheid, ander mense') dink en lewe en word - met vervaging van die eie individualiteit en die eie personale lewe en bestaan." ${ }^{\prime}$ )

Couwenberg sien die massafikasie as 'n ontvlugtingsreaksie van die mens ten einde vereensaming te ontduik. ${ }^{8}$ ) Die massamens moet voortdurend besig wees of besig gehou word. Hy moet lewe in lawaai en aktiwiteit. Hierdie mens ontvlug in die gewone alledaagsheid, in 'n roes van koorsagtige aktiwiteit wat veelal dwang- 
matig van aard is. Wanneer hierdie aktiwiteite wegval, verlustig dié mens hom in die verdowing van die radio, die bioskoop, dans, sport en vakansie wat meermale niks anders is nie as so 'n snel moontlike verplasing met die motor van die een plek na die ander.

Dit is duidelik dat daar in hierdie massafikasieproses kragte in die maatskappy werksaam is wat 'n sterk mate van onpersoonlikheid uitoefen. Verder het dit 'n meganisering, 'n standardisering en anonimisering van sowel die ekonomiese en arbeidsproses as die lewensgewoontes, ontspanning, openbare mening en dergelike tot gevolg. Kortom, die massafikasieproses lei tot die liggaamlike, geestelike en sedelike verproletarisering van die mens sodat hy uiteindelik ontredderd en van sy persoonlikheid ontneem aan die samelewing se eise konformeer.

Die indruk in hierdie sogenaamde massa-maatskappy val op spesialisasie, onpersoonlikheid, onbestendigheid, 'n gemis aan emosionele warmte en 'n oppervlakkige demokratisering van menslike behoeftes en gedrag. Couwenburg som die effek van die massafikasieproses soos volg op: „De geweldige vervlakking en kleurloosheid, het gemis aan werkelijke levensinhoud, levensdiepte en levenzin, waartoe het massaficatie-proces leidt, scheppen op den duur een wijdverbreide stemming van lusteloosheid, pessimisme, verveling en zelfs levenswalging. "') Wanneer 'n mens vra waarom die verskynsel van die massajeug 'n probleem geword het, gee $\mathrm{Nel}$ die volgende antwoord: ,.... eerstens, omdat dit 'n remmende invloed het op die mens as persoon en gevolglik die persoonlikheidsontwikkeling benadeel, met ander woorde, omdat die geestelike in die mens weerhou word om tot volle gedying te kom; tweedens, omdat dit hierdeur ' $n$ ondermynende invloed op die kulturele vorming van die mens het, en gevolglik die kultuur van 'n volk op 'n lae peil hou. ${ }^{10}$ )

As 'n mens die verskynsel van massafikasie in perspektief betrag, kan jy nie anders as om met Banning saam te stem nie dat ons massafikasie as 'n blywende verskynsel, ' $n$..... voortdurend ons begeleidende mogelijkheid..." sal moet aanvaar. ${ }^{11}$ ) Dat die voortsetting van die proses verreikende gevolge op die ontplooiing van ons jeugproblematiek kan hê, val nie te betwyfel nie.

\section{Die verhouding arbeid - vrye tyd.}

Die jeug leef tans in 'n era waarin die verhouding tussen arbeid en vrye tyd sterk geaksentueer word. Pieterse is van mening dat die mens van die moderne tyd oor die algemeen veel meer vrye tyd het as die mens van vroeëre geslagte. Hy konstateer voorts: „Hy (die moderne mens) tree in vergelyking met die mens van vroeër dae op 'n hoër ouderdom tot die arbeidsmark toe, werk minder ure 
per dag, bereik gouer die aftreeouderdom en leef langer. Die aanduidings bestaan dan ook dat die arbeidstyd in die toekoms nog verder sal verminder."12)

Hierdie probleem van die wanbalans tussen arbeid en vrye tyd moet gesien word as een van die gevolge van die tegniese evolusie en die geleidelike verstedeliking van die mensdom. Gesien die fenomenale tegnologiese en wetenskaplike ontwikkelinge van die afgelope dekade, kan verwag word dat die arbeidsduur in die nabye toekoms gevoelig sal verminder. Pieterse dui daarop dat die veertiguur-werksweek in verskeie lande 'n werklikheid geword het, dat die jaarlikse getal betaalde vakansiedae steeds verhoog en dat die mens in die V.S.A. tans gemiddeld $25,8 \%$ van sy lewe in vrye tyd deurbring, teenoor $24,4 \%$ van die Swede en $21,7 \%$ van diegene in Groot Brittanje. ${ }^{13}$ ) Fourastie se prognose vir Wes-Europa teen die jaar 2100 dui op ' $n$ berekening van veertig werksweke per jaar waarvan elk dertig werksure bevat, d.w.s. ses uur per dag in 'n vyfdag werksweek. ${ }^{11}$ )

Uit bogemelde opmerkings is dit duidelik dat al hoe minder tyd deur die mens se gewone arbeidsverpligtinge opgeslurp word, met die gevolg dat hy 'n groot hoeveelheid tyd tot sy beskikking het wat nie deur die reëlmatigheid, afgemetenheid en presiesheid van die beroepsarbeid opgeneem word nie. Die dilemma van ons tyd is juis geleë in die wyse waarop die mens hierdie beskikbare vrye tyd verwyl. In hierdie verband kan slegs met enkele opmerkings uit die verslag van die landwye jeugondersoek wat in die laat sestigerjare deur die Nasionale Jeugraad van die F.A.K. onderneem is, volstaan word. Ten opsigte van vryetydsbesteding is o.a. bevind dat die jeug hulle veral met passiewe en nie-skeppende aktiwiteite, wat gemik is op ontspanning en afleiding, besig hou. Hierteenoor kry die skeppende vryetydsbedrywighede, wat juis persoonlikheidsontwikkeling ten doel het, relatief min aftrek. ${ }^{15}$ )

Afgesien daarvan dat die aard van hulle vryetydsbesteding nie altyd bevorderlik is vir persoonlikheidsontwikkeling nie, bestaan die gevaar dat sommige vryetydsaktiwiteite juis negatiewe beinvloeding kan meebring. So blyk, bv., dat die oorgrote meerderheid van die jeugdiges $(75,2 \%)$ soms partytjies bywoon. ${ }^{16}$ ) Verder blyk dat $80,6 \%$ van die jeugdiges gewoonlik op dié partytjies dans, terwyl $78,8 \%$ rook en $52,5 \%$ sterk drank gebruik. ${ }^{17}$ ) Hierby kan nog gevoeg word dat $10,4 \%$ van die jeugdiges een keer per week alkoholiese drank gebruik, ${ }^{18}$ ) terwyl 48,1\% gewoonlik een tot drie drankies per geleentheid gebruik. ${ }^{19}$ )

Die passiewe, nie-skeppende en negatiewe vorme van ontspanning en vermaak moet waarskynlik ook gesien word teen die agtergrond van die kommersialisering van die vrye tyd en moontlik die permissiwiteit van die tydsgees waarin ons leef. 
Laastens moet beklemtoon word dat in ' $n$ periode van verminderde arbeidsduur dit noodsaaklik is om tot ' $n$ grondige besinning van die mens se arbeidsituasie te geraak. Veral moet in hierdie tyd klem gelê word op 'n deeglike beroepsoriëntering en -opleiding. In ' $n$ tegeniese arbeidsbestel bestaan daar ' $n$ groot behoefte aan geskoolde en gevormde persone met soepelheid en aanpassingsvermoë wat hulle in staat kan stel om meester te word van nuwe metodes en algehele vernuwing. ${ }^{30}$ )

\section{Diktatuur van gejaagdheid.}

Die gejaagde lewenstempo van die moderne mens - veral die leierskorps - neem vandag inderdaad 'n patologiese vorm aan. Meermale is juis die jeugdiges die prooi en die brandpunt van hierdie kunsmatige, onpersoonlike euwel.

Vanweë die enorme tegniese en wetenskaplike ontwikkelinge van die afgelope tyd, raak die mens 'n slagoffer van 'n oorvloed onsamehangende invloede en prikkels, oppervlakkige indrukke, vlugtige kontakte en maatskaplike eise en verpligtinge. Tyd om die uiterlike oorvloed te verwerk en te integreer in 'n sinvolle geheel, ontbreek met 'n gevolglike verbrokkeling van die menslike gees. Couwenburg stel dit treffend dat die mens ,geen tijd meer hebben, of beter gezegd, geen tijd meer nemen om zich rustig open te stellen voor de wêreld van de ander en voor het grootse natuurgebeuren, dat zich om hem heen voltrekt. ${ }^{21}$ )

Ons leef vandag onder 'n beklemmende diktatuur van gejaagdheid. Ons word meedoënloos meegesleur in 'n koorsagtige lewenstempo wat onverbiddelik uitmond in 'n diepe geestelike vermoeidheid waarin alles sinloos word. Die hedendaagse mens word gekondisioneer deur ' $n$ oorweldigende oorvloed van haastige indrukke en oppervlakkige verstrooiing, gedetermineerd om niks te mis of te ontglip nie. Hoewel daar 'n enorme uitbreiding van tussenmenslike kontak plaasvind, is die kwantiteit van sodanige kontakte omgekeerd eweredig met die kwaliteit daarvan.

Die jongmens streef egter juis daarna om persoonlike bande te smee, hy beleef juis die behoefte om, soos Spranger dit stel, ,,als een ,volle' eenheid te worden opgevat." ${ }^{2}$ ) V Vandaar dat Spranger ons samelewing vanuit die jeug se bril sien as "tot op't uiterste realistisch, absoluut zonder fantasie en zonder poësie. De jeugd heeft zich de wêreld zoo geheel anders gedroomd." ${ }^{23}$ )

Hierby kan nog gevoeg word dat die tempo van maatskaplike verandering immer sneller word. Die mens word so oordonder met die nuwe dat hy nouliks die geleentheid en die tyd het om alles te verwerk. Bowendien word sy lewe soms so oorheers deur die gejaag na groter en beter prestasie dat 'n noodwendige verswakking van tradisionele bindinge en die vermindering van bindingsgeleent- 
hede intree - veral op die tussenmenslike vlak. Die gevolg is dat die mens beskore is om, soos Van den Berg dit uitdruk, „een onoverzienbare menigte van mensen te kennen en nauwelijks één vriend te hebben." ${ }^{. "-1}$ )

\section{Materialisme.}

In noue aansluiting by bogemelde kan die koorsagtige strewe na stoflike welvaart en tegniese vooruitgang waardeur die personale bestaan van die mens feitlik geheel en al verswelg word, genoem word. Barnes dui tereg aan dat ons hedendaagse ekonomiese stelsel, wat grootliks om die kapitalisme sentreer, beheer word deur kapitalistiese finansiers wat as't ware die hoëpriesters van die nuwe monetêre teologie vorm. Hy vervolg voorts deur te sê dat ons byna oorgegaan het ,into an era in which the capitalistic economy and its accompanying lore have practically displaced supernatural thelogy." ${ }^{25}$ )

Die oorheersende najaag van materiële voorspoed lei tot 'n sosiaal-ekonomiese differensiasie wat veral in die stede kulmineer in diepgaande klasseverskille. Die vraag ontstaan nou of die mens nie miskien die slagoffer kan word van die welvaart en vooruitgang wat immers veronderstel is om tot sy voordeel te strek nie. Die rede vir laasgemelde aanname is geleë in die gedagte dat die dolle strewe na materiële gewin veelal gepaard gaan met die miskenning van tradisionele waardes en norme - dié dinge wat geld nie kan koop of vervang nie.

Die indruk bestaan wel dat ook die jeug vandag vasgevang is in die netwerk van materiële voorspoed en die strewe na groter stoflike welvaart. Hoewel talryke voorbeelde in dié verband voor die oog is, kan slegs verwys word na die feit dat $41,9 \%$ van die jeugdiges in die reeds gemelde jeugondersoek, reeds een tot drie keer en meer van beroep verwissel het. As dan gelet word op die redes waarom daar ontoereikende belangstelling in die betrokke beroep is, blyk dat die grootste enkele persentasie van diegene wat wel probleme in die opsig vertoon $(6,4 \%)$, die inkomste wat uit die beroep verkry word, as ontoereikend beskou. ${ }^{26}$ )

\section{Die Begripsgaping.}

Die sogenaamde "generation gap" tussen die ouer en die jonger geslag, is ' $n$ aspek van ons jeugproblematiek wat in die afgelope tyd sterk beklemtoon word. Met opregte kommer (en veelal met ' $n$ groot omhaal van woorde) word dan gelet op die feit dat die ouer en jonger geslag mekaar nie meer kan vind nie, dat hulle mekaar nie verstaan nie en as't ware by mekaar verbyleef. Dikwels word die verwyt vir dié toestand dan aan die voordeur van die jeug gelê. 
Die snelle ontwikkeling op só vele terreine - ook in ons menslike verhoudinge - $k a n$ in hierdie verband, byvoorbeeld, weer op die gesinslewe van toepassing gemaak word. Dit is algemeen bekend dat die gesinslede vandag grootliks geindividualiseerd lewe en nie meer die onderlinge lotsverbondenheid en kragtige eenheid van vroeër openbaar nie. Elke gesinslid bevorder sy eie belange op arbeidsgebied, op ekonomiese terrein, t.o.v. sy ontspanning en vryetydsbesteding, opvoeding ensomeer.

As ons hierby die enorme dinamiek van ons samelewing en die geweldige ontwikkelingsmoontlikhede wat dit bied, in gedagte hou, dan is dit bykans begryplik dat daar verskille in ontwikkeling en belangstelling tussen ouers en kinders sal ontstaan. Dit kan onderlinge vervreemding in die gesin in die hand werk wat die saamlewe in die gesin ernstig kan bemoeilik. Die verskynsel doen hom voor dat die kinders die ouers ontgroei. Hierdie ontgroeiing - en die gevolglike begripsgaping - kan aan velerlei faktore toegeskryf word. Kinders het nie alleen dikwels ' $n$ beter skoolopleiding gevolg en daardeur met dinge in aanraking gekom wat vir die ouers 'n geslote boek is nie, maar hulle word ook meegesleur deur die kragtige dinamiek van die samelewing waardeur hulle oor allerlei sake anders dink en 'n ander mentaliteit en geestesinstelling as dié waarin hulle ouers opgegroei het, opbou.

In 'n besinning oor die probleme in die proses van volwassenheidswording, kom Kruk tot die gevolgtrekking dat hierdie proses sowel 'n versnelling as 'n vertraging ondergaan het. ${ }^{27}$ ) $\mathrm{Hy}$ vervolg: „Men zou op grond van deze acceleratieverschijnselen kunnen pleiten voor een versnelde introductie van de jeugd in de wereld der volwassenen."2s) Hier moet egter steeds met individuele verskille rekening gehou word. Voorts kan daar op sommige terreine van die geestelike lewe wel 'n versnelling bestaan, terwyl op andere weer 'n vertraging kan voorkom. Moontlik varieer hierdie verskynsel ook van groep tot groep afhangende van die milieu waarin die jeugdige grootword en sy opvoeding ontvang. ${ }^{29}$ )

Wilhelm Roessler, wat 'n groot voorstander van die versnellingsteorie is, merk op dat baie ouers en onderwysers die nuwe ontwikkelings op geestelike en maatskaplike terrein hoegenaamd nie kan verwerk nie. Hulle eie opvoeding laat hulle in die veranderende omstandighede in die steek, met die gevolg dat hulle nie aan die jeugdige die nodige leiding en juiste steun kan bied nie. Hy raak tot die volgende slotsom: ,Zij (die ouers/onderwysers) blijven het proberen met de van ouds beproefde middelen en als die falen, wijten ze de mislukking aan de kinderen."30)

J. H. van den Berg betoog, hierteenoor, dat dit in die eerste plek nie die jeug nie, maar die volwassene en die wêreld van die volwassene is wat verander het. Hierdie verandering is drieërlei van aard. Eerstens het baie maatskaplike instellings polivalent 
geword. „Elke handeling”, so skryf hy, ,elke zaak en daarmee elk woord bezitten niet éên maar steeds vele betekenissen... Het kind, dat naar deze pluriforme en polyvalente volwassenheid toegroeit, ontmoet haast onoverkomelijke moeilijkheden. Elke stap, die het doet om volwassen te worden, is een stap in de mist der polyvalenties. ${ }^{. "}$ )

As tweede oorsaak van die verandering in die volwasse wêreld noem Van den Berg "die onsigbaarheid van die volwasse staat". Die jongmens sien en ervaar steeds minder van die lewe van die volwassene, veral op die gebied van die arbeid en die seksuele lewe. Die onsigbaarwording van die arbeidslewe van die volwassene bemoeilik o.a. die jeugdige se beroepskeuse. Verder word norme nie altoos baie duidelik gestel nie. Dikwels maak volwassenes hulle skuldig aan 'n dubbele moraliteit: prediking verskil van die daad. Gevolglik beland die jongmens in ' $n$ vakuum van verwarring.

Die verandering van die wêreldbeeld, as belemmering in die proses van volwassenheidswording, $k$ an as derde oorsaak in die veranderde volwasse wêreld genoem word. Die vanselfsprekende het uit die lewe verdwyn. Ons leef tans in ' $n$ gerasionaliseerde wêreld waarin verskynsels nie meer as sodanig aanvaar word nie. Alles moet bevraagteken en verklaar word.

Die veranderde volwasse wêreld, wat hierbo geskets is, is vir die kind ontoeganklik. Die eventuele gevolg is dat daar ' $n$ gaping in die wedersydse begrip tussen oud en jonk ontwikkel. Dit veroorsaak dat daar blykbaar vandag ' $n$ gapende kloof tussen die verskillende generasies ontstaan wat skynbaar onoorbrugbaar en baie diep voorkom.

\section{Permissiwiteit.}

Een van die grootste bedreigings van die Weste is dat die na-oorlogse liberalisme met sy gepaardgaande sedelike en kulturele permissiwiteit blykbaar besig is om die oorheersende lewenshouding by die Westerse volke te word. ${ }^{32}$ ) Volgens mnr. Jannie Kruger vind die nuwe wêreld gestalte in die oppermagtigheid van die kreet: .power" - veral „Black Power", .,Student Power”, en „Trade Union Power", wat op sy beurt voortvloei uit die hoogty van liberalisme en sosialisme met hulle sleepsel van permissiwiteit. ${ }^{33}$ ) Pieterse meen: .,In die geskiedenis van die Westerse wêreld sal die sewentiger jare van hierdie eeu seer sekerlik bekend staan as die dekade van permissiwiteit ... ' $n$ tydperk waarin meer en meer vergunnings gemaak is ten opsigte van die gedrag van die mens... jare waarin die vryheid van die mens tot sy uiterste gevoer word, sonder om 'n woord te rep van die verantwoordelikheid en gebondenheid wat juis deur vryheid veronderstel word. ${ }^{\prime 34}$ ) 
Die skynbaar toenemende losbandigheid op sedelike, godsdienstige, geestelike en morele gebied, wek tereg kommer van almal wat met meer as bloot akademiese belangstelling die jeug bejeën. Die bedoeling is nie om vervolgens in breë besonderhede op die onderhawige aspek in te gaan nie. Slegs enkele opmerkings word gemaak.

.Waar jeugdiges vroeër oor te veel gesag gekla het, is hulle klagte vandag teen te min gesag - een van die redes waarom jeugdiges ook nie meer in dieselfde mate aan hulle huise gebind is nie en waarom hulle hul behoeftes buite die huis wil bevredig", aldus Pieterse. ${ }^{3 i}$ ) Ons moderne gesinslewe vertoon, in vergelyking met die gesagstruktuur in die patriargale stelsel, ' $n$ verhouding van kameraadskaplike gelykberegtiging. Aan die een kant is die outoritêre vaderfiguur besig om te verdwyn en aan die ander kant speel die moeder ' $n$ steeds prominenter rol. Dit bring mee dat die jong, opgroeiende kind, die allerbelangrike geleentheid tot identifikasie met die outoritêre vaderfiguur moet ontbeer. Meermale word hierdie behoefte aan ' $n$ identifikasiefiguur dan buite die huis bevredig. Gepaard hiermee kry ons die verset van die jeug teen die oorgefunksionaliseerde en oorgeorganiseerde samelewing. Nel konstateer: "By die jeug is daar ' $n$ ontvlugting van oororganisasie, oorfunksionalisasie, die gejaagdheid, die gebrek aan leiding en gesag in die gesin en daarom bevind hulle hulleself op straat, waar hulle besig is om ' $n$ eie lewenshouding, ' $n$ eie subkultuur te skep. ${ }^{.36}$ )

In hierdie verband moet kortliks gelet word op die dilemma van die werkende jongmense wat dikwels met 'n elementêre opleiding aan die onpersoonlike verswelging van die stadslewe oorgelewer word. Ontdaan van die nodige geestelike toerusting, kan hierdie mense nie die ervarings van 'n gekompliseerde lewe verwerk nie. Volgens Couwenburg betree hierdie jong mense ,... een wereld van dreunende machines, harde zakelijkheid en ver doorgevoerde gespecialiseerde arbeid, welke hemelsbreed verschilt van het vertrouwde gezins- en schoolmilieu - terwijl ze juist in de zo gevoelige en kwestbare periode van de puberteit zijn." ${ }^{3 i}$ ) Hulle verrig verbeeldinglose roetine werk en arbeid is dikwels vir hulle ' $n$ noodsaaklike kwaad. Nel konkludeer in dié verband soos volg: .Hulle lewensgevoel en lewensingesteldheid, asook hulle ongevormdheid, maak hulle maklik 'n slagoffer van uiterlike faktore soos die moderne vorme van vermaak ..." ${ }^{38}$ )

In die afgelope tyd het ook ons studente te staan gekom voor die stormramme van ' $n$ nuwe geestelike aanslag. Om vas te stel in hoeverre die studentegemeenskap in Suid-Afrika gebeuk het voor die aanslag van die nuwe kultuurorde, kan slegs verwys word na die verskeie woelinge wat in die betrokke studente-organisasies heers. Hierdie woelinge sentreer veral om die kreet van sosiale en politieke verandering. Daar kan seker op talle wyses aangetoon 
word dat die studentegeledere onmiskenbare invloede van die denkwyses en aktiwiteite van oorsese studente openbaar. Veral kan in die opsig verwys word na die propaganda vir die nuwe mode van 'n nivelleringsproses waar die sug van één volk, één godsdiens en één kultuur voortdurend geslaak word. Die feit dat liberale elemente onder die studentekorps die bestaande kultuurorde as teiken kies, is beslis nie sonder goeie rede nie. Die aftakeling van kultuurwaardes is immers die kwesbaarste terrein waarop 'n gemeenskap en 'n volk so ontredder kan word dat hy sonder veel teenstand vatbaar kan wees vir die aanvaarding van 'n „nuwe”, „volksvreemde” ideologie in sy leef-en denkpatroon.

Wanneer voorts op die verskeie vorme waarin permissiwiteit sigself openbaar, gelet word, stuit mens voor 'n legio van voorbeelde. Kruger som dit aldus op: „Alles is veroorloof, inbegrepe die misbruik van verdowingsmiddels; die botviering van geweld; die integrasie van wat wesenlik verskil, selfs ongelyk is, soos verskillende rasse; versaking van gesag deur ouers en die verwerping van dissipline en tug deur die jeug; die uitkolking van die heiligdom van die menslike liggaam en die ekshibisie en eksploitasie van seks. ${ }^{39}$ )

In die jongste tyd het veral die probleem van dwelmmiddelmisbruik groot aandag geniet. Hoewel alle instansies en wetenskaplikes huiwerig is om hulle uit te spreek oor die ware omvang van dié verskynsel, is oppervlakkige aanduidings daar dat die probleem ruimer in omvang is, as wat algemeen besef word. In die V.S.A. wissel menings met betrekking tot die persentasie studente wat LSD gebruik tussen $2,5 \%$ en $10 \%$ tot $15 \%{ }^{10}$ ) In 'n projeksie wat deur Bewley in die Verenigde Koninkryk gedoen is, word bereken dat, uitgedruk per 100000 van die bevolking, 800 tot 1200 persone barbiturate gereeld gebruik (hoewel hulle nie afhanklik daarvan is nie); 100 tot 200 mense amfetamines in 'n ligte en erger graad misbruik en dat 30 tot 60 mense die Cannabis-soorte (ons dagga) misbruik. Slegs een per 100000 van die bevolking maak hulle skuldig aan misbruik van die hallusinogene (waaronder LSD). ${ }^{41}$ ) Jones wys daarop dat die getal heroien verslaafdes in die Verenigde Koninkryk in die tydperk 1963 tot 1966 vanaf 635 tot 1349 gestyg het. Betekenisvol is ook dat hy aantoon dat waar geen van die heroien verslaafdes in 1959 onder 20 jaar was nie, 317 in 1966 in die ouderdomsgroep onder 20 jaar en 479 in die groep tussen 20 en 34 jaar geval het. ${ }^{42}$ ) Rip toon ten opsigte van die Blankes in SuidAfrika aan dat die grootste getal veroordelings weens dagga in 1958 tot 1962 in die ouderdomsgroep 17 tot 20 jaar voorgekom het. Daarna volg die groep van 21 jaar en ouer. ${ }^{43}$ )

Met betrekking tot die verskynsel van jeugmisdaad kan ook rede tot kommer uitgespreek word. Venter toon byvoorbeeld aan dat die syfers vir 1960 op 'n geweldige styging in Blanke jeugmisdaad dui - veral by die groep 17 tot 20 jaar. Terwyl die omvang in die 
geval van die jeugdiges ( $7.16 \mathrm{jr}$.) ietwat toegeneem het van 40,1 per 100000 van die bevolking in 1954 tot 40,6 in 1960, is die toename by die jeugdige volwassene (17-20 jr.) in dieselfde tydperk vanaf 465,9 in 1954 tot 602,5 in 1960.44 ) Bowendien dui gemelde skrywer aan dat aggressiewe misdade besig is om toe te neem. Hy konstateer: „Die toename in geweldsmisdrywe en sedelikheidsdelikte is ' $n$ aanduiding van ' $n$ proses van verruwing en die vervalsing van waardes wat sedert die Tweede Wêreldoorlog ingetree het. ${ }^{.45}$ )

Die misbruik van alkoholiese drank en die verandering van sedelik-morele waardes verdien verdere aandag. In die jeugondersoek van die F.A.K. se Nasionale Jeugraad, het die grootste enkele persentasie van die jeugdiges wat nie geheelonthouers is nie, $\mathrm{nl}$. $31,8 \%$, gesê dat hulle agt en meer drankies in die voorafgaande sewe dae geneem het. Hiervan was $26.7 \%$ tussen 16 en 18 jaar, $38,7 \%$ tussen 19 en 21 jaar terwyl 33,7\% in die ouderdomsgroep 22 tot 25 jaar geval het. ${ }^{4 i}$ ) In 'n ondersoek by die lowa College in die V.S.A., waar driekwart van die proefpersone byna 21 jaar oud was, het Ira Reiss die verandering van standaarde met betrekking tot seksuele permissiwiteit nagegaan. Van die damestudente wat hulle opvattings oor die seksuele lewe in die voorhuwelikse verhouding een maal verander het, het $47 \%$ tans soen goedgekeur, terwyl $47 \%$ „petting” en $6 \%$ coitus aanvaar het. Waar die gemelde opvattinge twee maal gewysig is, het $17 \%$ soen, $79 \%$,petting" en $14 \%$ coitus as standaard gestel. Waar die standaard vir 'n derde of meer kere verander is, het $53 \%$ coiltus goedgekeur. Wat die mans betref, het $16 \%$ soen, $36 \%$ „petting" en $48 \%$ coitus by die eerste wysiging goedgekeur, terwyl $36 \%$,petting" en $64 \%$ coitus met die tweede en $100 \%$ coitus by die derde verandering van standaarde goedgekeur het. ${ }^{4 i}$ ) "Petting" is omskryf as "sexually stimulating behaviour more intimate than kissing and simple hugging but not including full sexual relations." ${ }^{.18}$ )

Etlike terreine waarop groeiende permissiwiteit voorkom, kan nog hier geĩdentifiseer word. 'n Mens dink, byvoorbeeld, aan die toenemende onrus oor die moord- en selfmoordsyfers, die dolle gang van gesinsdisorganisasie en -ontbinding, die verskynsels van promiskuiteit, ontug en die stemme wat opgaan vir die algehele wettiging van aborsies. Hierbenewens kan genoem word dat die aktiwiteite op die aandelebeurs, die waagstukke van makelaars en individue, asook die uitvloei van geld na die casino's van ons buurstate, waarskynlik op die lang duur ewe verreikende gevolge kan hê as die mees flagrante loterye in Rhodesië. Laastens kan vermeld word dat ons perswese, die gedrukte woord in die algemeen en ons ander massamedia, nie die gees van permissiwiteit kon ontglip nie. So, byvoorbeeld, het ons perswese verstrik geraak in ' $n$ gekommersialiseerde netwerk wat sensasie of "warm" nuus moet opdis. 
Hiermee word groter sirkulasie en as gevolg daarvan ekstensiewer advertensies gewerf. Vandag, meer as ooit, moet ons pleit vir ' $n$ verantwoordelike perswese. Mnr. Jannie Kruger, voorsitter van die Publikasieraad, skryf in dié verband die volgende: „Ons wat by beheer en keuring van publikasies, films en vermaaklikhede betrokke is en daagliks aanskou hoe elke nuwe deurbraak van naakte seks, homoseks, LSD-,trips', cowboy-skiet-en-skop-films ... en ander uitwasse van permissiwiteit om binnelating teen ons poorte beuk: ons, sê ek, is in staat om te oordeel tot watter laagtes van verwording die Westerse beskawing gesink het." 19

Bogemelde is dan in breë trekke 'n poging om enigsins ' $n$ beeld te skep van die wgreld waarin die jeug van ons tyd leef. Vervolgens wil, ten slotte, enkele riglyne getrek word waarmee getrag sal word om o.a. moontlike weë aan te dui waarlangs die huidige jeugproblematiek dalk benader kan word.

\section{ENKELE RIGLYNE VIR MOONTLIKE WEË WAARLANGS ONS JEUGPROBLEME BENADER KAN WORD.}

Wanneer gedink word aan moontlike wyses waarop jeugprobleme benader kan word, is die versoeking uiteraard groot om op breedsprakige wyse aandag te skenk aan die betekenisvolle rol wat die gesin, die kerk, die skool en ander organisasies in dié verband kan vervul. Die bedoeling van hierdie bespreking is egter geensins om in gedetailleerde besonderhede in te gaan nie. Daar is talle persone en talryke instansies wat op georganiseerde grondslag besig is om met die jeugproblematiek te worstel en hulle voortdurend op die hoogte te hou met die effektiwiteit van verskillende modi operandi op hierdie vlak. 'n Poging sal derhalwe aangewend word om by die reeds bestaande gedagtes aan te sluit en daarvandaan enkele riglyne aan te dui.

As basiese vertrekpunt kan kortliks gelet word op Van Hessen se indeling van die drie sosiale dimensies (milieus) waarin die huidige jongmens se lewe afspeel. ${ }^{50}$ ) Die rede hiervoor is dat die jeugdige in sy volwasse-wording grootliks deur hierdie drie dimensies, nl. die gesin, die sekondêre institute en die sgn. „derde millieu”, beinvloed word.

\section{Die Gesin.}

Die gesin waarvan die jongmens lid is, beheers en beheer ten dele sy hele lewe. Weliswaar word hierdie invloed met verloop van die jeugfase geringer, maar dit bly tog groter as wat baie pessimiste veronderstel. So, byvoorbeeld, het die landwye jeugondersoek van die F.A.K. gevind dat die grootste enkele persentasie van die jongmense $(27,8 \%)$ hulle jongste vakansie by die ouerhuis deurgebring het. Die verslag lui voorts: „In soverre werkende jongmense vir hulle 
vakansie huistoe gaan, dui dit na alle waarskynlikheid op 'n lewendige gesinsgebondenheid, wat nog nie, soos veelal gemeen word, iets van die verlede is nie. ${ }^{\prime \prime 1}$ )

Ons durf dus nie sover gaan om die huisgesin te bestempel as 'n plek „dat enkel nog diende als servicestation om te eten en te slapen" nie. ${ }^{52}$ ) Die jeugdige van vandag konformeer nog in 'n groot mate aan die norme en waardes van sy gesin van herkoms. Hulle wil hulle ook grootliks bly toets aan die gangbare standaarde van hierdie gesin. Al ontwikkel hulle later ook 'n groter selfstandigheid, ervaar hulle nog graag die werking en deurwerking van die gesin van herkoms.

Aan die ander kant kan dit nie ontken word nie dat ons in 'n geindustrialiseerde en burokratiese gemeenskap lewe waarin daar weinig strukturele kontinuiteit met die gesin bestaan. Enersyds bestaan daar die intimiteit en beskerming van die gesinslewe en andersyds die onpersoonlike gerasionaliseerde en georganiseerde gemeenskap. Dit bring mee dat die jeugdige, wanneer hy die intieme gesinsfeer verlaat, moet inskakel by 'n sosiale struktuur wat in vele opsigte van die gesinspatroon verskil. Die gesin het dus die allesoorkoepelende roeping om die lewende kultuur van die samelewing op 'n besondere wyse op sy lede af te stem. Cammaer stel dit soos volg: "Leven als een kind betekent groeiend mens-zijn in konfrontasie met levende menselijkheid en levende kultuur, waarbij het gezin als filter optreedt zowel voor wat vanuit de maatschappij naar het kind toekomt als voor de kontakten die het kind zelf geleidelijk naar de maatschappij toe gaat uitbouwen. Als het gezin in deze funktie deficiënt is, dan is het leven van het kind en zijn ingroeien in de menselijke maatschappij vertekend. ${ }^{\prime \top 3}$ )

Hierdie omstandighede stel besondere eise aan die algemene gesinsverhoudinge en die posisie van die ouers in die besonder. Die ou patriargaal-outoritêre gesinstruktuur waarin die vader 'n oorheersende en die moeder 'n ondergeskikte rol vervul het, tree tans terug vir 'n gesinstruktuur waarin daar meer kameraadskaplike verhoudings aanwesig is en waarin 'n toestand van gelykberegtiging heers. Die outoritêre vaderfiguur verdwyn nou en die moeder tree op die voorgrond. Hierdie verskynsel het belangwekkende pedagogiese implikasies. ${ }^{54}$ ) Die kind het behoefte aan 'n vaderfiguur wat vir hom tegelyk gesag en leiding asook 'n identifikasiefiguur bied. Die gevolg is dat die vader is 'n slap figuur beskou word, wyl die moeder die funksie as 'n plaasvervangende vader moet vervul.

Die tyd breek egter, volgens Beets, aan dat die vaderrol in die nabye toekoms sal verander van 'n blote onderhouding van mense na die kreatiewe vorming van mense. ${ }^{55}$ ) Die vader sal weer huiswaarts keer en minder deur die louter tegniese en matematiese in beslag geneem word. Die man in ons geindustrialiseerde samelewing staan op die punt om meer vrye tyd in ontvangs te neem. Die vraag 
is hoe hy hiervan gebruik sal maak. Die man wat tuiskom, sal meer tyd hê vir homself, sy vrou en sy kinders. Die aandag wat hy aan hulle verleen, sal 'n beroep doen op sy fantasie, sy visie, sy oorspronklikheid en sy kreatiwiteit. Tereg vra Beets die vraag: „Word het niet tijd dat aan de voorbereiding op het vader-zijn, in het bijzonder wat betreft de opvoeding van oudere kinderen, evenveel aandacht wordt geschonken als aan de voorligting van jonge moeders over baby- en kleuterverzorging ${ }^{\prime \prime 5 j}$ )

Die moderne vader sal verder moet leer om bewuste keuses te maak: om homself te beperk. Hier dink mens veral aan die vaders wat so besig is om ' $n$ bydrae aan die gemeenskap te lewer dat hulleself en hulle gesinne daaronder ly. Die man moet meester wees van sy tyd, nie 'n slaaf nie. Dit sal sy gemoedsrus, sy bloeddruk, sy slaap, asook sy maag- en hartprobleme ten goede strek. Die volgende uittreksel uit 'n ope brief aan „commissielijders” in die Tijdschrift voor maatschappelijk werk van J. F. de Jongh, dien as rigtingwyser vir die hedendaagse vader: „Wij weigeren verder deel uit te maken van commissies en besturen, waarin wij niet een eigen bijdrage kunnen leveren... Wij maken geen, afspraken' meer voor zaken die eenvoudig genoeg zijn om per brief te worden afgedaan. Wij gaan alleen maar naar grote congressen toe, wanneer wij er plezier in hebben, om een dag uit te zijn en om nog eens met een aantal collega's te praten. Wij gaan er dus beslist niet meer naar toe wanneer wij alleen maar referaten moeten aanhoren, die veel beter kunnen worden gelezen. Wij gaan er ook niet meer heen om onszelf te vertonen. Ook voor plechtigheden ... nemen wij als vaste regel, dat wij alleen verschijnen als wij er toevallig plezier in hebben."s7)

Met die terugkeer van die vader in die gesin, kan die moeder ophou om 'n kwasie-vader te wees. Sy kan nou opnuut vorm gee aan haar lewe. Haar arbeid in die huis kan weer bevredigend en sinvol raak. Dit sal egter vir vele vroue nie 'n maklike omwenteling wees nie. Hier word gedink aan die vrou wat haar werkplek, die organisasies waarvan sy lid is, die magsposisies wat sy beklee en die sosiale funksies moeilik sal afsweer. Baie vroue het hulle in die emansipasieproses en in hulle verlange na gelykwaardigheid en vryheid, te veel met die man vereenselwig. Ook die vrou moet dus tot haarself kom as eggenote en as moeder.

Die gesin sal met die terugkeer van die vader en die moeder nuwe daadkrag openbaar. Dit sal versnippering van die gesinslewe teenwerk en 'n geordender lewensbestaan aan die gesinslede meebring. Dit sal die gesin verder in staat stel om hom met toewyding aan sy groot rol en funksievervulling in die hedendaagse gemeenskap te wy. ${ }^{58}$ )

In hierdie verband moet klem gelê word op die besondere behoeftes wat die pasgetroude jong egpaar ondervind. Daar is verskeie faktore wat 'n sosiale heroriëntasie van die jonggetroude in 
die hand werk, bv., bande met ou kennisse word verbreek, nuwe vriende moet gemaak word, as gevolg van 'n ontoereikende begroting of deur die geboorte van 'n eersteling word ' $n$ beperkte mobiliteit veroorsaak en dergelike meer. ${ }^{59}$ ) Voorbereiding vir die huwelik is deel van die opvoedingsproses wat ook in die huisgesin van krag moet wees. Die beeld van 'n gelukkige huisgesin en gesinslewe word aanhoudend deur kommersiële en reklame-agente wat meer yskaste, wasmasjiene en verf wil verkoop, aan die jeugdige voorgehou. Dikwels gee dit die ongebalanseerdste en kunsmatigste prentjie van wat die huwelik, die gesin en die huishouding behels.

Een van die probleme wat deesdae baie prominensie verkry, is die begripsgaping tussen die jongmens en die volwassene. Hierdie gaping ontstaan veelal vanweë die konflik in die jeug se emansipasieproses. Dikwels word dit ook vergesel van 'n goeie dosis aggressiwiteit deurdat die jeugdige sy wêreld stel en kontrasteer met diê van die volwassene. Die jongmens voel altyd min of meer ' $n$ behoefte om die posisie van die volwassene oor te neem.

By dit alles blyk dat die ouer geslag nie meer met die jeug kommunikeer nie. Daarom reageer die jeug ook nie. Die ouer spreek dikwels nie meer die taal van sy kind nie. Dis dus nie alleen ' $n$ vraagstuk van 'n onbegrypbare jeug nie, maar ook ' $n$ vraagstuk van 'n onbegrypbare ouer of volwassene. Kranenburg is die volgende mening toegedaan: ,De ouderen leven te veel in een andere (vaak zelfs voorbijgegane) wereld en nemen als vanzelfsprekend aan dat de jongeren zich bij hén moeten aanpassen. De ouderen zullen zich evenzeer ernstig moeten afvragen, waardoor zij zover van de huidige generatie verwijderd zijn geraakt. ${ }^{.60}$ )

Die samelewing is tans gerig op selfhandhawing, konkurrensie en winsbejag. Daarom is dit deels te begrype dat die jeug skepties, utilisties en skynbaar minder idealisties ingestel, voorkom. Ouers en ander volwassenes verwag dat idealisme ' $n$ plek in die jeug se gedagtewêreld moet inneem, dog ook dat hulle handelinge op die reële en die bestaanstryd gerig moet wees. Hierdie gespletenheid skep verwarring waaroor die jeugdige duidelikheid soek. Op hierdie en soortgelyke probleme kan die volwasse nie altyd pasklare antwoorde verskaf nie. Hieroor hoef die volwassene hom egter nie te skaam nie. "Wel moeten ze zich ervoor schamen als ze tegenover de vragen van de jongeren zich in een schijn-heilighuisje teruktrekken om hun onmacht te verbergen", aldus Kranenburg. ${ }^{61}$ ) Dus, ten spyte van die gelykberegtiging en meebelewing in die gesin, word die bespreking van sekere sake vermy om die goeie verstandhouding te bly behou. Dit noop Nel om tot die gevolgtrekking te geraak dat hedendaagse ouers hulle net nie kan indink dat kinders soos vroeër, hulle moeilikhede het waaroor gesels moet word nie. ${ }^{62}$ ) Mays raak ongeveer dieselfde probleem aan wanneer hy soos volg skryf: „Young people almost everywhere, today as ever, are starved of 
sensible conversation. They lack opportunities to talk freely and confidentially with older people who have had more experience of life than themselves." 63 )

Laastens kan vermeld word dat die gesin seer sekerlik in die toekoms 'n deurslaggewende rol sal moet speel ten opsigte van sy lede se vryetydsbesteding. Ons nader 'n era waarin die beskawing van vrye tyd dreig om ons tot ' $n$ val te bring. $n$ ' Nuwe mens, wat die helfte van sy nuttige tyd aan sport en ontspanning sal kan wy, lê in die nabye verskiet. Hierdie mense moet nou gevorm word.

\section{Die sekondêre institute.}

'n Tweede dimensie waarin 'n groot deel van die jeugdige se lewe afspeel, is die sektore van die samelewing waar jonglui onder "dwang" van buite, saamgevoeg word in sgn. sekondêre institute, bv. in skole, die bedryfslewe, militêre diensplig ensomeer. ${ }^{64}$ ) Vir praktiese doeleindes word die kerk ook hieronder ingedeel. In hierdie verband word met 'n paar bondige opmerkings volstaan.

Die skool is die belangrikste skakel wat deur die samelewing daargestel is om die jongmens sistematies in te lei in die geheel en totaliteit van die kultuur en die funksionering van die samelewing. Die oogmerk is o.a. dat die jongeling sal uitgroei tot ' $n$ volwassene wat met sy hele persoonlikheid en met volle verantwoordelikheid die lewe in sy omgewing en die kultuur van sy groep kan meedra. Die opdrag van die skool is dus enorm groot en vra nie alleen sistematiese beplanning, ordening en programmering nie, maar ook hulp van alle persone en instansies wat daartoe bevoeg is. Die skool moet voortdurend sy vinger op die pols van die kultuurlewe hou en, indien nodig, van tyd tot tyd die gewenste aanpassings maak. Boweal moet die skool nie so verhewe wees dat hy hom nie kan onderwerp aan kritiese selfondersoek ten einde te bepaal watter elemente uit die aktuele lewe om nadere betragtiging vra nie.

Ons moet voor oë hou dat die doel van die onderwys is om die jongmens as volwassene suksesvol by die samelewing te laat inskakel. Hierdie samelewing is dinamies en verander voortdurend. Gevolglik verg dit in baie opsigte aanpassings van die skool se kant. Ten opsigte van die skool in die V.S.A., skryf Barnes, bv., soos volg: "Much of our current educational curriculum is sadly irrelevant and has little or no relation to the social problems of the twentieth century." ${ }^{\text {"65) }}$ Tereg merk Beets op dat die skool toekomsgerig moet wees want sodanige skool het die beeld van die volwasse mens in sig, 'n mens wat teen die lewe opgewasse is, genees is van die siekte van die huidige tyd en nie verward staan teenoor die invloede uit sy milieu nie. ${ }^{.6}$ ) Kortliks kom dit dus hierop neer dat die skool maatreëls moet tref vir die positiewe vorming van die kind se persoonlikheid sodat hy skeppend, selfs te midde van ongunstige 
omstandighede kan optree. In hierdie verband kan die gedagte van onderwysowerhede om jeugweerbaarheid as 'n moontlike skoolvak te oorweeg, dalk kostelike vrugte oplewer.

Die predikant en die jeugvereniging kan waarskynlik namens die kerk die belangrikste bydrae lewer. Hieronder word meer oor die jeugvereniging in die algemeen kwytgeraak. Wat die verhouding tussen die predikant en die jeug betref, bestaan daar skynbaar ook ruimte vir verbetering. So, bv., blyk uit die landwye jeugondersoek van die F.A.K. dat in slegs $46,8 \%$ van die gevalle daar 'n persoonlike gesprek tussen die leraar en die jeugdige tydens voorbereiding tot kerklidmaatskap plaasgevind het. ${ }^{{ }^{-}}$) Verder blyk dat die aandrang van die leraar slegs in $8,7 \%$ van die gevalle 'n faktor was wat die jeug by ' $n$ kerklike jeugvereniging laat aansluit het. ${ }^{63}$ ) Wanneer die jeug persoonlike probleme ondervind, verkies slegs $5,1 \%$ om die leraar te raadpleeg. ${ }^{69}$ ) Van die universiteitstudente beweer, $25,0 \%$ dat hulle geen persoonlike kontak met hulle leraar tydens hulle studiejare gehad het nie.")

Hieruit blyk genoegsame motivering vir Groenendijk se kommer dat daar 'n ernstige gebrek aan "gemeenzaamheidsbesef" tussen die predikant en die gelowige bestaan. ${ }^{21}$ ) Die gevolg hiervan is, volgens Couwenburg, dat daar ,geen echt persoonlijk samenzijn meer tussen beiden (is), geen echte liefde tot elkaar met als gevolg dat de priester alleen nog ambtelijk aan de gelovige verschijnt en deze slechts in een of andere traditionele en onpersoonlijke godsdienstige daad zich veilig stelt tegenover het instituut der Kerk en via deze Kerk tegenover God." ${ }^{\prime 2}$ ) Selfs tydens huisbesoek, so meen hy, ,verloopt alles volgens schema en ontstaat er bijna nooit een echt gesprek van (Christen) mens tot mens. Alles blijft op het niveau van de prestatie, de nuttigheid en bereikt slechts hoogst zelden de sfeer van zingeving aan het gelovig bestaan zelf, de vreugde van de ontmoeting in Christus." ${ }^{23}$ )

Uit dié enkele opmerkings blyk dat die predikant 'n revaluasie van sy verhouding tot die gelowiges in die algemeen en die jeug in die besonder moet maak. Die leraar moet verder besef dat die toekoms besondere eise aan sy verhouding met sy gemeentelede sal stel - eise waarvoor hy met die nodige kennis, vakmanskap en kundigheid toegerus sal moet wees. Derhalwe is dit gepas om hier 'n pleidooi te lewer dat persone in die humanitêre (of mens-) professies bv. predikante, on derwysers, dosente, ens., beter opgelei word om met mense en veral jongmense te werk. Kennis van die sosiologie, sielkunde, maatskaplike werk, pedagogiek en soortgelyke wetenskappe, is vandag essensieel vir enige persoon wat op ' $n$ vakkundige wyse met mense wil werk. Wanneer ' $n$ man ' $n$ tand wil laat trek, gaan hy na ' $n$ deskundige, wanneer hy ongesteld is, besoek hy die beste geneesheer, aan sy motor mag net die beste werktuigkundige swoeg, maar met betrekking tot die moeiliker probleme op 
sosio-ekonomiese en politieke gebied, is hy tevrede met die mening van die man op straat. Die tyd is verby dat mense wat opgelei is vir ander professies, soos tans die geval is, met welslae gebruik kan word om leiding te gee en behulpsaam te wees met betekenisvolle jeugwerk. Hiervoor is vakkundige kennis en geskooldheid nodig.

\section{Die "derde milieu".}

Naas die gesin en die sekondêre institute handhaaf en kultiveer die jongmens 'n besondere betrokkenheid met mede jeugdiges. Die konglomeraat van groepsverhoudinge wat in hierdie betrokkenheid neerslag vind en wat in baie opsigte as die sosiale kern van die jeugbestaan ervaar word, kan aangedui word as die sgn. „derde jeugmilieu".. ${ }^{4}$ ) Die invloed van volwassenes is weliswaar nie totaal geëlimineer nie, dog skuif op die agtergrond. Dit hou verder in dat die intensiteit van die jeugbestaan sy optimum vind in die uitdrukkinge, verwagtinge, norme, simbole en voorstellinge van hierdie milieu. Bevry van die formeel organisatoriese druk van, bv., 'n skoolsisteem en die beroepswêreld, word die derde milieu juis gekenmerk deur 'n groter plastisiteit van sosiale vormgewing en 'n groter elastisiteit van funksionering. Uiteindelik is die sosiale identiteit van die jeugdige nie soseer herkenbaar via sy inskakeling in gesin, skool of bedryf nie, maar vanweë die bepaalde struktuur wat sigself in die derde milieu voltrek. ${ }^{i 5}$ )

Gesien die breë terrein van die jeuglewe wat deur die derde jeugmilieu geraak word, is die versoeking natuurlik groot om hier in fyner besonderhede enkele aspekte te deurvors. Skrywer weerhou hom egter doelbewus - ofskoon moeilik - hiervan en wys slegs op 'n paar fasette van een aspek, nl. die jeugvereniging of jeugbeweging in die algemeen. Wanneer die jeugvereniging hier uitgesonder word, beteken dit egter hoegenaamd nie dat so ' $n$ vereniging (en tewens die derde milieu as sodanig) geisoleer kan word of los van die gesin en sekondêre institute kan bestaan nie.

Die reeds gemelde jeugondersoek het aangetoon dat slegs $35.7 \%$ van die jongmense lid van 'n klub en/of vereniging is. ${ }^{76}$ ) Uit 'n ondersoek na die Afrikaanse jeugorganisasies, blyk dat verveeldheid $(20,7 \%)$ as die belangrikste rede aangedui word waarom jeugdiges nie by sodanige organisasies aansluit/bly nie, ${ }^{77}$ ) m.a.w. die betrokke organisasie bevredig nie hulle behoeftes nie, belangeloosheid ontstaan en dit gee aanleiding tot die ontwikkeling van negatiewe gevoelens in die groep.

Oor die algemeen sou mens kan sê dat ons jeugverenigings in die jongste verlede waarskynlik meer konserverend as stimulerend van aard was. 'n Jeugvereniging vertoon dikwels die neiging om dit as vanselfsprekend aan te neem dat hy uit sy opdrag en doelstelling tegelyk die juiste metodiek in die hande het om sin aan sy bestaan 
te gee. Meermale word die dinamiek, soms selfs die kwaliteit, van dié jeugwerk deur hierdie misverstand in die wiele gery. Een van die rewolusionêrste veranderinge van toekomstige jeugwerk sal waarskynlik wees dat die ideale, wat van oudsher besiel het, vervang sal word deur saaklike insig in die konkreet bereikbare. Kranenburg konstateer: „De moderne jeugd leeft veel minder voor de verre horizonten dan voor het voor-de-hand-liggende en grijpbare." is)

Die doel van die jeugvereniging moet deur die jeug as sinvol, maar ook as noodsaaklik beleef word. Voorts moet dit ' $n$ spesifieke doel wees en nie een wat gemik is op die algemene vorming van die jeug nie. Ons moet laat vaar om die jeugvereniging te rig op .die jeug" en hulle sodoende betreklik ongedifferensieerd te benader. Die vraag ontstaan of mense nie wesenlik te abstrak, te totalitêr, te onpersoonlik en dus te organisatories aan die jeug dink nie. Jeugwerk moet gedifferensieer wees omdat jongmense en hulle bepaalde behoeftes nie tot algemeenhede gereduseer kan word nie. So, byvoorbeeld, is dit vanselfsprekend dat differensiasie volgens leeftyd moet plaasvind. Hier word verder gedink aan differensiasie volgens sosiologies-omskrewe milieus, ten opsigte van gestremdes, verskillende kultuurgroepe, asook die oogmerke van die organisasie.

'n Jeugorganisasie wat hom nie bloot met steriele bewaring besig nou nie, maar met beweging en vitaliteit, berus nie net op die inisiatief en geesdrif van die jeug nie, maar is ook afhanklik van die inspirasie van sy leiers. Wanneer een of albei ontbreek, ontstaan daar 'n kortsluiting. Hoewel die jeug self nie altyd duidelik aanvoel waarheen hulle moet nie, al kan hulle die konsekwensies van hulle optrede nie altyd peil nie en al is hulle houding miskien soekend en vraend, sal die leiding in die toekoms in ' $n$ groter mate op die intuisie van die jeug berus en sal hulle rigtinggewende perspektief moet aandui.

Dit wil voorkom asof ons jeugorganisasies juis mank gaan aan besielde en goed opgeleide leiers. 'n Volskaalse rekrutering van leiers vir ons jeugbewegings skyn dus essensieel. Dit behoef in ons tyd ook geen betoog dat spesiale eise van opvoedkundige aard van hierdie mense gestel moet word nie. Burokratisering van ons jeuglewe is gevaarlik. Die Staat en ook provinsiale en plaaslike owerhede moet genader word om toegewyde en deskundige leiers te lewer. Hierdie persone moet oor die nodige vakkundigheid beskik, iets wat 'n inter-dissiplinêre opleiding aan 'n universiteit kan bied. SuidAfrika is een van die weinige lande in die Weste wat haar nie volskaals bemoei met die vorming en opleiding van jeugwerkers en jeugleiers nie.

Terselfdertyd het die tyd nou aangebreek dat jeugdiges groter inspraak (seggenskap) in jeugorganisasies verleen word. Van elke platform word vertroue in die jeug uitgespreek, tog word hulle selde 
vertroue waardig geag deur, bv., aan hulle verantwoordelikhede te skenk. Hoe meer jongmense inspraak en medeverantwoordelikheid verkry, des te groter is die kans dat burokratisering en tegnokrasie vermy word.

Daar bestaan tans ook 'n dringende behoefte vir die effektiewe koördinasie van ons jeugwerk in die algemeen en die jeugorganisasies in die besonder. Een van die basiese uitgangspunte by koördinasie bly natuurlik die outonomie van die deelhebbende organisasies. ${ }^{79}$ ) Koördinasie kan besonder bevrugtend en heilsaam op ons jeugorganisasies inwerk. Veral die Staat kan ernstig daaraan dink om sy eie jeugaksie te koördineer. Tans word jeugwerk deur verskeie Staatsdepartemente onderneem, o.a. die Departemente van Nasionale Opvoeding, Sport en Ontspanning, Arbeid en Volkswelsyn. Die versnippering oor verskeie ministeries en die eiematigheid van die verskillende dienste, bevorder nie 'n doelmatige jeugbeleid nie.

Dit is miskien wenslik dat 'n Minister van Jeugsake spesiaal belas word met die hele .jeugproblematiek. Hierdie Minister kan regstreeks verantwoordelik wees vir die jeugbeleid en op 'n nasionale vlak die pleitbesorger van jeugbelange wees. Ofskoon moeilik en delikaat, moet aan hierdie Minister die koördinasie tussen die jeugbeleid van die regering, asook dié van die provinsiale en plaaslike owerhede opgedra word. Sodanige Minister kan verder die gevoelige kwessie van subsidiëring aan jeugorganisasies behartig. Ook met betrekking tot die uitbouing van 'n netwerk van infrastrukture vir die jeugwerk kan hierdie Minister belangrike werk verrig, bv. ten opsigte van vormings- en ontspanningsentra, sportkomplekse, jeugburo's en dergelike meer. Hierdie Minister se belangrikste taak sal waarskynlik wees om voortdurende wetenskaplike navorsing oor jeugsake aan te moedig. Hier word gedink aan die daarstelling van 'n Instituut vir Jeugnavorsing (soortgelyk aan, of desnoods 'n vaste onderafdeling van die huidige Raad vir Geesteswetenskaplike Navorsing), wat nie alleen plaaslike navorsing moet onderneem nie, maar hom voortdurend op die hoogte moet hou van bevindings van ondersoeke regoor die wêreld en die beskikbaarstelling van sodanige gegewens.

Hierbo is in alle beskeidenheid gepoog om enkele weë vir 'n moontlike benadering van ons jeugwerk aan te dui. Dat hiermee nie die laaste woord gespreek is nie, is voor die hand liggend. Feit is egter dat diegene wat hulle met die jeug bemoei, in die toekoms, met meer as net akademiese belangstelling en goeie bedoelings op hierdie terrein werksaam sal moet wees. Indien die jeug ook nie met die nodige geloof en vertroue bejeën word nie, kan ' $n$ mens hulle weë moontlik vir 'n tyd lank manipuleer, hulle vir 'n ruk in gemaklike konsumpsie isoleer, maar uiteindelik sal sulke politiek wrange vrugte meebring. 
1) Van Hessen, J.: .Jeugdwerk in sociologisch vizier", oordruk uit Die Ontmoeting, Van Corcum en Comp. N.V., Assen, 1969; p. 29.

2) Vgl. in dié verband: - Couwenburg, S. W.: De Vereenzaming van de Modeme Mens, 2e druk, N.V. Uitgeversmaatschappij Pax, 's- Gravenhage. 1957; pp. 23 e.v.

3) Vgl. Nel, B. F.: 'n Modem-pedagogiese benadering van jeugprobleme, Serie Verdiept Inzicht, Deel IX, In opdrag van die Stichting Onderwijs Oriëntatie. Amsterdam 1961; p. 2.

4) Van Echelpoel, J., Cammaer, H., Yperman, J., Leirman, W., en Peeters, K.: Jeugdwerk in perspektief, De Nederlandsche Boekhandel, Antwerpen, 1969; p. 14.

5) Ibid., p. 16.

6) Ibid., p. 17.

7) Cronjế, G.: "Die mens in die moderne wêreld", Voorsittersrede gehou tydens die jaarvergadering van die S.A. Akademie vir Wetenskap en Kuns, soos gerapporteer in Hoofstad, 9 Augustus 1971, p. 12 (eerste aflewering) en 10 Augustus 1971, p. 12 (tweede aflewering).

8) Couwenburg, S. W., op. cit., p. 67.

9) Ibid., p. 69.

10) Nel, B. F., op. cit., p. 19.

11) Banning, W.: Moderne Maatschappij-Problemen, $5 c$ druk, De Erven F. Bohn N.V., Haarlem 1960; p. 91 e.v.

12) Pieterse, J. E.: .,Die mens en sy Vrve Tyd", 'n Referaat gelewer tydens die jaarvergadering van die S.A. Akademie vir Wetenskap en Kuns, Julie 1971; p. 2.

13) Ibid., p. 2.

14) Van Echelpoel, J. (e.a.), op. cit., p. 19.

15) Vgl. Pieterse, J. E. (Voorsitter Redaksiekomitee): Jeugkongres, Verslag van die Jeugondersoek, Deel V. Voortrekkerpers Bpk., Johannesburg. 1968; p. 61 e.v., vgl. ook. Pieterse, J. E. (Hoofredakteur): Jeug en Vrye Tyd, Verslag van die Jeugondersoek, Deel III, Voortrekkerpers Bpk., Johannesburg, 1968; p. 10 e.v.

16) Pieterse, J. E. (Hoofredakteur): Jeug en Vrye Tyd, p. 120.

17) Ibid., p. 123.

18) Ibid., p. 127.

19) Ibid., p. 128.

20) Vgl. Van Echelpoel, J. (e.a.), op. cit., p. 22.

21) Couwenburg. S. W., op. cit., p. 38.

22) Spranger, E.: Psycholog:e der Jeugd, 12de druk, N.V. Uitgevers-Maatschappij, s.j.; p. 183.

23) Ibid., p. 183.

24) Couwenburg, S. W., op. cit., p. 39.

25) Barnes, H. E.: Society in Transition, Prentice-Hall Inc., New York, 1942; p. 950.

26) Pieterse, J. E. (Hoofredakteur): Jeug en Arbsid, Verslag van die Jeugondersoek, Deel I. Voortrekkerpers Bpk., Johannesburg, 1968; p. 66 e.v.

27) Kruk, R. W.: Begeleiding der volwassenwording, Serie Verdiept Inzicht, Deel XI, opdrag van die Stichting Onderwijs Oriëntatie, Amsterdam, 1961; p. 14 e.v.

28) Ibid., p. 15

29) Ibid., p. 15

30) Ibid., p. 15

31) Ibid., p. 16

32) Cronié, op. cit., p. 12

33) Vgl. Kruger, Janie: „Die Toekoms van die Afrikaner in die Nuwe Wêreld”. Handhaaf, Amptelike maandblad van die F.A.K., Februarie 1970; p. 12.

34) Pieterse, J. E.: „Die Mens en sy Vrye Tyd”, p. 7.

35) Ibid., p. 10.

36) Nel, B. F., op. ict., p. 36.

37) Couwenburg, S. W., op. cit., p. 56.

38) Nel, B. F., op. cit., p. 31.

39) Kruger, Jannie, op. cit., p. 12.

40) De Bold, R. C. en Leaf, R. C.: LSD, Man and Society, Faber and Faber, London, 1969; p. 36 e.v.

41) Willis, J. H.: Drug Dependence, Faber and Faber, London, 1969; p. 24.

42) Jones, Terence: Drugs and the Police, Butterworths, London, 1968; p. 11 e.v. 
43) Rip, C. M.: Contemporary Social Pathology, Academica, Pretoria/Kaapstad, 1966; p. 100.

44) Venter, H. J.: Jeugmisdaad, Craft Pers Bpk., Pretoria, 1965; p. 12.

45) Ibid., p. 16.

46) Pieterse. J. E. (Hoofredakteur): Jeug en Vrye Tyd, p. 133.

47) Reiss, I. L.: The Social Context of Premarital Sexual Perm ssiveness, Holt, Rinehart and Winston, Inc., 1967; p. 106 e.v.

48) Ibid., p. 198.

49) Kruger, Jannie, op. cit., p. 12

50) Van Hessen, J., op. cit., p. 31 e.v.

51) Pieterse, J. E. (Hoofredakteur): Jeug en Vrye Tyd, p. 15.

52) Van Hessen, J., op. cit., p. 31

53) Van Echelpoel, J. (e.a.), op. cit., p. 75.

54) Vgl. Nel, B. F., op. cit., p. 35 e.v.

55) Beets, N.: Volwassen Worden, Erven J. Bijleveld, Utrecht, 1961; p. 224 e.v.

56) Ibid., p. 225

57) Ibid., p. 225.

58) Vir vollediger besonderhede vgl. o.a. Cronjé, G.: Mens tot Medemens, 3de uitgawe, H.A.U.M., Kaapstad, 1968; p. 230 e.v.

59) Vgl. De Klerk, L.: Beginnende volwassenheid, De Toorts, Haarlem, s.j.; p. 151 e.v.

60) De Ruyter, T. H., Van Houten, B. W., Kranenburg. S. (Red.): Jeugd en Samenleving. Nijgh en Van Ditmar, 's Gravenhage, 1964; p. 181.

61) Ibid., p. 181 .

62) Nel, B. F., op. cit., p. 38.

63) Mays, J. B.: The Young Pretenders, Michael Joseph, London, 1965; p. 195.

64 Van Hessen, J., op. cit., p. 31.

65) Barnes, H. E., op. cit., p. 968.

66) Beets, N., o.p. cit., p. 231.

67) Pieterse, J. E. (Hoofredakteur): Jeug en Godsdens, Verslag van die Jeugondersoek, Deel IV, Voortrekkerpers Bpk., Johannesburg, 1968; p. 43.

68) Ibid., p. 50.

69) Ibid., p. 29.

70) Ibid., p. 54.

71) Couwenburg, S. W., op. cit., p. 34.

72) Ibid., p. 34.

73) Ibid., p. 34.

74) Vgl. Van Hessen, J., op. cit., p. 32 e.v.

75) Vgl. Ibid., p. 35 e.v.

76) Pieterse, J. E. (Hoofredakteur): Jeug en Vrye Tyd. p. 144.

77) Ibid., p. 157.

78) De Ruyter. T. H. (e.a.), op. cit., p. 185.

79) Vir vollediger besonderhede vgl. Pieterse, J. E. (Voorsitter Redaksiekomitee): Jeugkongres, p. 75 e.v. 